JESTT Vol. 2 No. 11 November 2015

\title{
PENCAPAIAN MASLAHAH MELALUI ETIKA BISNIS ISLAM STUDI KASUS RESTORAN MIE AKHIRAT"1)
}

\author{
Dany Hidayat \\ Mahasiswa Program Studi S1 Ekonomi Islam_fakultas EKonomi dan Bisnis-Universitas Airlangga \\ Email: danyhidayat09@gmail.com
}

Fatin Fadhilah Hasib

Departemen Ekonomi Syariah-Fakultas Ekonomi dan Bisnis-Universitas Airlangga Email: fatin.fadhilah@gmail.com

\begin{abstract}
:
This research aims to understand the implementation of business ethics within the restaurant "Mie Akhirat". This Research uses a qualitative approach entailing a descriptive case study of the object and a purposive sampling technique. The data used are collected through a semistructured interview. Analysis of data is carried out by using the descriptive analysis model. The result of this research is expected to reveal the business ethics implemented within the restaurant. This research hopes to benefit by exposing examples of islamic business ethics implemented by the restaurant. This research suggests that the implementation of islamic business ethics would be of great benefit for the whole of society including their economic condition.
\end{abstract}

Keywords: Islamic Business Ethics, Maslahah, Restaurant Business, Mie Akhirat

\section{PENDAHULUAN}

Manusia adalah makhluk sosial yang membutuhkan orang lain untuk memenuhi kebutuhan hidupnya, keadaan ini menciptakan sebuah sistem yang dapat menimbulkan orang lain untuk memproduksi serta mendistribusikan barang dan jasa dengan tujuan untuk memenuhi kebutuhan. Manusia adalah makhluk sosial yang membutuhkan orang lain untuk memenuhi kebutuhan hidupnya, keadaan ini menciptakan sebuah sistem yang dapat menimbulkan orang lain untuk memproduksi serta mendistribusikan barang dan jasa dengan tujuan untuk memenuhi kebutuhan.

Agama Islam mengajarkan untuk melakukan praktik ekonomi berdasarkan norma - norma dan etika yang di perbolehkan dalam Islam. Seorang ekonom dapat memelajari cara praktik bisnis Islam yang berdasarkan ajaran tauhid, dimana hal ini sudah diakui oleh para ekonom muslim maupun non muslim. Al - Quran juga menjelaskan dalam surat At-Taubah ayat 111:

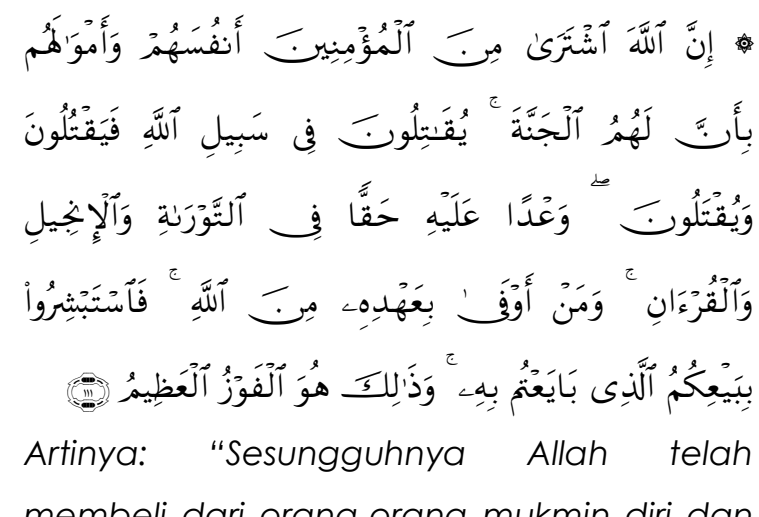
membeli dari orang-orang mukmin diri dan

1) Jurnal ini merupakan bagian skripsi dari Dany Hidayat, NIM : 041114001 , yang diuji pada tanggal 10 Agustus 2015 
harta mereka dengan memberikan surga untuk mereka. mereka berperang pada jalan Allah; lalu mereka membunuh atau terbunuh. (Itu telah menjadi) janji yang benar dari Allah di dalam Taurat, Injil dan Al Quran. dan siapakah yang lebih menepati janjinya (selain) daripada Allah? Maka bergembiralah dengan jual beli yang telah kamu lakukan itu, dan Itulah kemenangan yang besar" (QS. At-Taubah: 111: DEPAG 2009).

Bisnis adalah kegiatan muamalah, seperti yang dijelaskan pada ayat ini bahwa manunia mencari kelebihan karunia Allah dengan berbisnis tetapi tidak lupa untuk tetap mengutamakan shalat. AlQur'an menggaris bawahi bahwa dorongan yang seharusnya lebih besar bagi dorongan bisnis adalah memperoleh apa yang berada di sisi Allah (Hizrian, 2014).

Manusia memiliki kodrat untuk bergelut di bidang ekonomi, baik untuk kepentingan pribadi maupun kepentingan bersama (kolektif) guna memenuhi kebutuhan hidup yang tidak terbatas dengan sumber yang terbatas. Manusia bertanggung jawab sebagai pihak yang berperan aktif dalam peningkatan taraf hidup manusia baik secara individu maupun universal.

Manusia pada era modern ini banyak yang memahami bisnis hanya sebatas bisnis dengan tujuan utama untuk memperoleh keuntungan sebanyak- banyaknya. Hukum Ekonomi Klasik yang menggunakan modal sekecil mungkin dan mengeruk keuntungan sebanyakbanyaknya ini telah membuat banyak orang yang menjadi pelaku bisnis dengan menghalalkan segala cara untuk meraih keuntungan. Menghalalkan segala cara tersebut dapat dilihat dari cara memperoleh bahan mentah, cara produksi, tempat produksi, tenaga kerjanya serta pemasarannya dilakukan seefektif dan seefisien mungkin tidak perduli kepentingan atau akibat yang akan timbul yang akan diterima orang lain.

Bisnis menjadi sebuah realitas yang kompleks, banyak hal dapat mempengaruhi kegiatan bisnis. Bisnis juga dapat di katakan sebagai kegiatan sosial dengan kompleksitasnya di masyarakat, hal ini di karenakan masyarakat dan pebisnis memiliki kepentingan yang sama. Seorang pebisnis memiliki tangung jawab terhadap konsumen, karyawan, komunitas dan lingkungan dalam segala aspek yang berhubungan dengan bisnisnya. Di Indonesia terdapat undang-undang yang mengatur tentang hak dan kewajiban perilaku pelaku usaha dan konsumen agar tidak ada pihak yang perlakukan secara tidak adil, undang-undang yang mengatur adalah UU no 8 tahun 1999 tentang Perlindungan Konsumen. Kewajiban pelaku usaha diatur dalam pasal 7. Bisnis memiliki tanggung jawab sosial 
yang membuat bisnis bukanlah aktivitas maupun entitas yang berdiri sendiri, tetapi terikat oleh sistem-sistem kemasyarakatan. Banyak pelaku bisnis yang jarang memperhatikan tanggung jawab sosial dan mengabaikan etika bisnis. Etika bisnis dibutuhkan sebagai pengawal dan pengontrol bisnis agar tidak keluar dari hakikat bisnis tanpa melanggar nilai-nilai agama, hukum pemerintah dan nilai-nilai yang ada di masyarakat.

Di dalam Islam, etika bisnis Islam menuntut dan mengarahkan kaum muslimin untuk melakukan tindakan sesuai dengan apa yang dibolehkan dan dilarang oleh Allah SWT termasuk dalam melaksanakan aktivitas ekonomi. Manusia bebas melakukan kegiatan ekonomi untuk meningkatkan taraf hidupnya.

Tokoh yang dapat menjadi contoh sebagai pelaku bisnis yang sukses dan memiliki perilaku bisnis yang baik adalah Nabi Muhammad SAW. Perilaku Beliau dalam berbisnis dalam Islam dapat dijadikan kajian tentang etika bisnis. Mental Nabi Muhammad SAW untuk menjadi pekerja keras telah di bentuk sejak masih kecil. Para pebisnis banyak yang ingin bekerjasama dengan Nabi Muhammad SAW karena gelar Al - Amin yang di dapatkannya. Kesibukannya dalam berbisnis membuat Nabi Muhammad SAW menjadi pelaku bisnis yang professional dengan mempertimbangkan etika bisnis yang di yakininya. Nabi Muhammad SAW juga selalu bersikap adil dalam berbisnis, maksudnya Nabi Muhammad SAW tidak pernah melakukan kecurangan dalam menimbang atau mengukur barang yang diperjualbelikan, selain itu barang yang dijual juga selalu barang yang halal.

Etika dalam bisnis berfungsi untuk menolong pebisnis untuk memecahkan permasalahan yang berkaitan dengan moral dalam praktek bisnis yang mereka hadapi. Etika bisnis Islam harus di pahami secara benar sehingga kemungkinan kehancuran bisnis akan kecil dan dengan etika bisnis yang benar tidak akan yang merasa dirugikan dan mungkin masyarakat dapat menerima manfaat yang banyak dari kegiatan jual beli yang dilakukan.

Berdasarkan permasalahan perekonomian yang terjadi saat ini, entrepreneur dapat menjadi solusi yang paling tepat. Entrepreneur dapat membantu untuk menciptakan lapangan kerja baru, meningkatkan pemerataan pendapatan, meningkatkan produktivitas nasional dan yang paling penting dapat meningkatkan kesejahteraan ekonomi masyarakat tersebut. Badan Pusat Statistik menjelaskan bahwa hingga tahun 2014 jumlah total penduduk Indonesia adalah 237.641.326 juta jiwa, dari jumlah tersebut terdapat 118,17 juta penduduk Indonesia yang bekerja dan hanya 44,20 juta orang yang menjadi entrepreneur. Data tersebut 
meningkat dari tahun sebelumnya yang hanya 44,10 juta orang, hal ini menunjukkan bahwa minat orang - orang untuk menjadi entrepreneur semakin meningkat.

Entrepreneur telah menjadi pendorong dari perekonomian negara. Entrepreneur juga telah menjadi budaya tersendiri di kalangan masyarakat sehingga memiliki ciri aturan yang mungkin tidak tertulis. Aturan tersebut dapat berupa etika dalam berbisnis. Rasulullah SAW juga telah memberikan contoh bagaimana melakukan bisnis, meskipun dalam kenyataannya di kehidupan sehari-hari masih banyak di temukan permasalahan permasalahan yang berkaitan dengan penyimpangan dalam menghadapi dan memperlakukan konsumen / pembeli yang tidak sesuai dengan etika berbisnis Islam yang berdasarkan pada Al - Quran dan Hadits.

Penelitian ini dibuat untuk mengetahui bagaimana implementasi etika bisnis Islam pada aktivitas bisnis Restoran Mie Akhirat. Sehingga dapat diambil manfaat yang mungkin berguna untuk orang lain.

\section{LANDASAN TEORI}

Etika Islam yang telah menyatu kedalam bisnis menciptakan paradigma bisnis kedalam sistem etika bisnis Islam. Paradigma bisnis juga dikatakan sebagai cara pandang yang dijadikan landasan bisnis sebagai aktivitas maupun entitas. Paradigma bisnis Islam di bangun dan di landasi oleh prinsip-prinsip berikut (Naqvi, 1993:86-105) :

1. Kesatuan

Tauhid dalam agama, menjelaskan bahwa manusia mengakui keesaan Allah SWT dan meyakini bahwa semua bersumber dari Allah SWT. Prinsip kesatuan yang menyatu kedalam konsep tauhid telah memadukan keseluruhan aspek-aspek kehidupan muslim baik dalam bidang ekonomi, politik, dan sosial. Berdasarkan konsep ini, Islam menawarkan agar agama, ekonomi dan sosial membentuk sebuah kesatuan. Berdasarkan hal ini pula etika dan bisnis menjadi suatu persamaan yang penting dalam sistem Islam.

Berdasarkan aksioma diatas maka seorang pengusaha muslim harusnya tidak melakukan hal-hal berikut dalam aktivitas bisnisnya (Beekun, 1997:20-23) :

a. Diskriminasi diantara pekerja, penjual, pembeli, mitra kerja atas dasar pertimbangan ras, warna kulit, jenis kelamin atau agama.

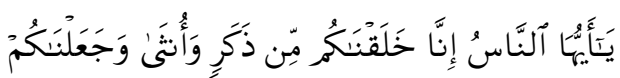

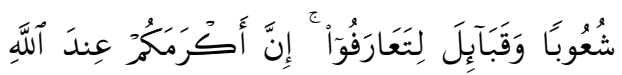

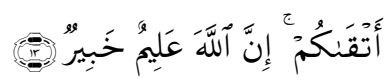

$$
\begin{aligned}
& \text { Artinya: "Hai manusia, } \\
& \text { Sesungguhnya Kami menciptakan } \\
& \text { kamu dari seorang laki-laki dan }
\end{aligned}
$$


seorang perempuan dan menjadikan kamu berbangsabangsa dan bersuku-suku supaya kamu saling kenal-mengenal. Sesungguhnya orang yang paling mulia diantara kamu disisi Allah ialah orang yang paling taqwa diantara kamu. Sesungguhnya Allah Maha mengetahui lagi Maha Mengenal" (QS. Al-Hujuurat:13: DEPAG,2009)

b. Terpaksa atau dipaksa untuk melakukan praktek-praktek mal bisnis karena hanya Allah lah yang semestinya ditakuti dan di cintai.

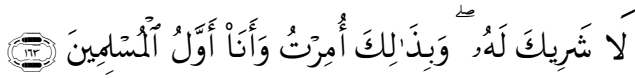

Artinya: "Tiada sekutu bagiNya; dan demikian Itulah yang diperintahkan kepadaku dan aku adalah orang yang pertama-tama menyerahkan diri (kepada Allah) ". (QS.AlAn'am:163:DEPAG,2009)

C. Menimbun kekayan atau serakah karena hakikatnya kekayaan merupakan Amanah Allah.

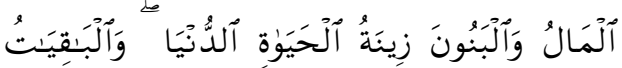

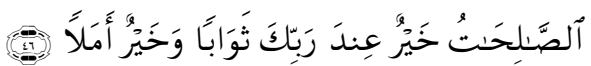

Artinya: "Harta dan anak-anak adalah perhiasan kehidupan dunia tetapi amalan-amalan yang kekal lagi saleh adalah lebih baik pahalanya di sisi Tuhanmu serta lebih baik untuk menjadi harapan" (QS.Al-Kahfi:46:DEPAG,2009).

2. Kesetimbangan (Keadilan)

Islam selalu mengajarkan untuk berbuat adil kepada pihak manapun tanpa perkecualian, termasuk kepada pihak yang tidak disukai baik saat beraktivitas di dunia kerja maupun bisnis. Perilaku seimbang atau adil telah dijelaskan dalam teori klasik bisnis agar pengusaha muslim jujur, contohnya seperti memberikan takaran yang tepat dan menimbang dengan adil dan benar dengan alat ukur yang pas.

Menurut Nawatmi (2010:57) wujud dalam praktek keseimbangan dalam bisnis ialah dengan tidak ada kecurangan dalam takaran dan timbangan serta penentuan harga berdasarkan mekanisme pasar yang normal. Sesuai dengan firman Allah SWT. dalam QS.AI-Isra' ayat 35

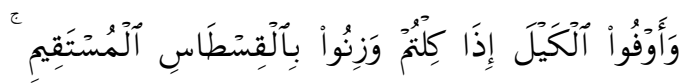

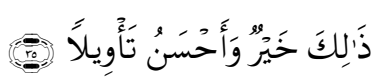
Artinya: "dan sempurnakanlah takaran apabila kamu menakar, dan timbanglah dengan neraca yang benar. Itulah yang lebih utama 
(bagimu) dan lebih baik akibatnya" (QS.Al-Isra':35:DEPAG, 2009).

Keadilan dalam dalam Al Quran disebutkan dengan mengunakan kata al-adl dan al-qitsh. Hasil analisis terhadap penggunaan kata al-adl dalam Al-quran berarti tebusan, sama, sesuai dengan apa adanya, memberikan hak yang sama dan memberikan penjelasan atau informasi sebagaimana adanya (Zenrif, 2006:101). Para pakar agama dalam Shihab (2013:152-155) berpendapat terdapat empat makna keadilan, yakni adil dalam arti sama, adil dalam arti seimbang, adil dalam perhatian terhadap hak-hak individu, dan terakhir adil yang dinisbatkan pada ilahi yang berarti memelihara kewajaran atas berlanjutnya eksistensi, tidak mencegah kelanjutan eksistensi dan perolehan rahmat sewaktu terdapat kemungkinan untuk itu.

3. Kehendak Bebas

Bagian terpenting dalam nilai etika bisnis Islam adalah kebebasan, dimana kebebasan tersebut tidak merugikan kepentingan bersama. Setiap orang bebas untuk aktif berkarya dan bekerja dengan kemampuan yang di milikinya. Kebebasan yang di maksud bukanlah bebas sebebas-bebasnya dalam menciptakan produk, pendistribusian maupun dalam mengkonsumsinya tetapi terikat dengan aturan agama Islam. Contohnya adalah tentang manusia yang terus-menerus memenuhi kebutuhannya yang tidak terbatas. Pengendalian kebutuhan tidak terbatasnya adalah dengan adanya kewajiban setiap individu untuk membayar zakat, infak dan sedekah.

Manusia diberi kehendak bebas untuk membimbing kehidupannya sebagai khalifah, hal ini sesuai dengan firman Allah SWT dalam QS. Al-Kahfi Ayat 29

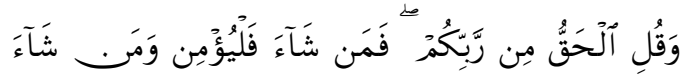

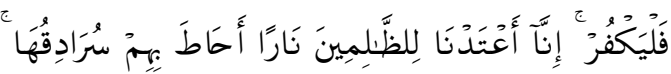

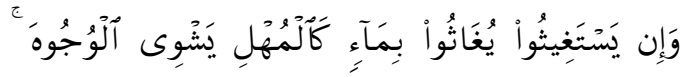

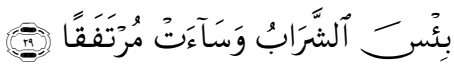
Artinya: "dan Katakanlah: "Kebenaran itu datangnya dari Tuhanmu; Maka Barangsiapa yang ingin (beriman) hendaklah ia beriman, dan Barangsiapa yang ingin (kafir) Biarlah ia kafir". Sesungguhnya Kami telah sediakan bagi orang orang zalim itu neraka, yang gejolaknya mengepung mereka. dan jika mereka meminta minum, niscaya mereka akan diberi minum dengan air seperti besi yang mendidih yang menghanguskan muka. Itulah minuman 
yang paling buruk dan tempat istirahat yang paling jelek"

(QS. Al-Kahfi:29:DEPAG:2009).

Berdasarkan hal ini, Nawatmi (2010:57) mengungkapkan bahwa dalam bisnis manusia punya kebebasan untuk membuat kesepakatan atau bekerja sama bukan untuk merugikan orang lain. Apabila terdapat persaingan maka persaingan tersebut haruslah sehat. Setelah kontrak atau kesepakatan dibuat maka masingmasing harus memenuhinya.

4. Tanggung Jawab

Kebebasan tanpa batas adalah yang tidak mungkin dilakukan oleh manusia. Manusia harus bertanggungjawab untuk setiap tindakannya. Prinsip ini berhubungan dengan kehendak bebas. Penetapan batasan mengenai apa yang bebas dilakukan oleh manusia dengan bertanggungjawab atas semua yang dilakukannya adalah hal yang penting.

Tanggung jawab manusia dalam bisnis adalah untuk memperbaiki lingkungan ekonomi dan sosial, maka tingat konsumsi harus di perhatikan dari segala aspek baik dalam tingkatan mikro maupun makro.

Menurut Nawatmi (2010:57), berdasarkan prinsip ini aplikasi yang dapat di terapkan dalam bisnis adalah: a. Upah harus disesuaikan dengan UMR (Upah Minimum Regional).

b. Economic return bagi pemebri pinajam modalharus dihitung berdasarkan perolehan keuntungan yang tidak dapat dipastikan jumlah-nya dan tidak bisa ditetapkan terlebih dahuluseperti dalam sisitem bunga.

c. Islam melarang semua transaksi seperti gharar, system ijon, dan sejenisnya.

5. Kebenaran: Kebajikan dan Kejujuran Prinsip kebenaran dalam konteks ini memiliki dua unsur yakni kebajikan dan kejujuran. Apabila dihubungkan dengan bisnis maka yang dimaksudkan dengan kebenaran adalah niat, sikap dan perilaku yang benar yang meliputi proses akad (transaksi), proses mencari, maupun dalam pengembangan usaha untuk meraih keuntungan yang diinginkan. Prinsip kebenaran ini sangat menjaga dan belaku hati-hati dengan kemungkinan adanya kerugian saat melakukan transaksi ataupun saat kerja sama.

Kebajikan merupakan tindakan yang memberi keuntungan bagi orang lain. Termasuk sikap kebajikan dalam bisnis adalah sikap kesukarelaan dan keramah- 
tamahan. Dalam berbisnis kedua belah pihak harus suka rela dan punya hak yang sama dalam hal penentuan transaksi maupun kesepakatan. Hal ini digunakan untuk menjaga hubungan silaturahmi antar sesama pelaku bisnis agar tetap baik. Di dalam bisnis kejujuran merupakan salah satu hal penting. Sri Nawatmi (2010:57) mengungkapkan bahwa ketika melakukan transaksi bisnis harus jujur dalam memberikan informasi produk dan dalam pemenuhan perjanjian. Selain itu pebisnis juga tidak boleh lupa untuk bersedekah, bersikap baik, memberikan kelonggaan untuk pihak terhutang dan membayar hutang sebelum ditagih.

\section{METODE PENELITIAN}

\section{Pendekatan Penelitian}

Dalam penelitian ini, pendekatan yang di gunakan adalah kualitatif deskriptif. Penelitian ini menggunakan strategi studi kasus.

\section{Ruang Lingkup Penelitian}

Ruang lingkup penelitian merupakan suatu batasan studi yang menjelaskan fokus studi agar tidak melebar pada masalah yang lain. Menurut sugiyono (2011:206), dalam penentuan fokus berdasarkan pada hasil studi pendahuluan, pengalaman, referensi, dan disarankan oleh pembimbing atau orang yang di anggap ahli. Penelitian ini akan fokus pada implementasi etika bisnis Islam pada kegiatan bisnis Restoran "Mie Akhirat".

\section{Jenis dan Sumber Data}

Menurut Lofland dan Lofland (1984:47) sebagaimana yang dikutip oleh Lexi J.Moleong bahwa sumber data utama dalam penelitian kualitatif ialah katakata dan tindakan selebihnya adalah data tambahan seperti dokumen dan lain-lain. Dimana data hasil penelitian didapatkan melalui dua sumber data, yaitu:

\section{Data Primer}

Data primer adalah data yang diperoleh langsung dari hasil wawancara yang diperoleh dari narasumber atau informan yang dianggap berpotensi dalam memberikan informasi yang relevan dan sebenarnya di lapangan.

\section{Data Sekunder}

Data sekunder adalah sebagai data pendukung data primer dari literature dan dokumen serta data yang diambil dari Restoran "Mie Akhirat" dengan permasalahan dilapangan yang terdapat pada lokasi penelitian berupa catatan atau laporan histories yang tersusun rapi (data dokumenter).

\section{Teknik Penentuan Informan}


JESTT Vol. 2 No. 11 November 2015

Penentuan informan dalam
penelitian ini menggunakan teknik
Purposive Sampling atau sampling
bertujuan. Purposive Sampling adalah
suatu strategi jika seseorang
menginginkan agar dapat memahami
sesuatu mengenai kasus - kasus terpilih
tertentu tanpa membutuhkan (atau
berhasrat) untuk menggeneralisasi
kepada semua kasus seperti itu.
Informan yang dibutuhkan adalah
owner atau pemilik usaha dan
karyawan yang berhubungan langsung
dengan pelanggan.

\subsection{Teknik Pengumpulan Data}

Penelitian ini menggunakan pengumpulan data sebagai berikut (Afifuddin fan Saebani, 2009:131) :

1. Survei pendahuluan

Survei pendahuluan dalam skripsi ini meliputi observasi dan peninjauan awal di Restoran "Mie Akhirat". Survei dilakukan dengan mendatangi secara langsung ke tempat narasumber yang bisa berada di Restoran "Mie Akhirat". Tujuan dilakukannya survei ini untuk memperoleh gambaran umum mengenai situasi dan kondisi di Restoran "Mie Akhirat".

\section{Penelitian Lapangan}

Dalam penelitan lapangan ini wawancara merupakan hal penting, hal ini dikarenakan dalam penelitian kualitatif lebih berupa kata - kata.
Penelitian dilakukan dengan wawancara secara langsung dengan pihak pengelola Restoran "Mie Akhirat". Teknik yang di gunakan untuk mendapatkan informan adalah jenis teknik purposive.

Selanjutnya hasil dari wawancara akan di deskripsikan dan di sarikan oleh peneliti. Jumlah informan yang di butuhkan dalam penelitian ini tergantung keberagaman informasi yang di terima oleh peneliti. Apabila saat penelitian berlangsung, informasi yang di dapat tidak berkembang dan dirasa telah mewakili apa yang diharapkan sebelumnya, pencarian informan berhenti pada saat itu juga.

3. Saat Pengumpulan Data

Peneliti mengumpulkan data primer yang meliputi : wawancara dan observasi pastisipatif. Peneliti akan melakukan wawancara terhadap pemilik atau pihak yang bertanggung jawab di Restoran "Mie Akhirat". Materi wawancara yang di persiapkan adalah pertanyaan yang dapat berkembang disesuaikan dengan informan yang ditemui. Wawancara berakhir apabila informasi yang dibutuhkan telah di dapatkan dan tidak ada informasi baru lagi yang berkaitan dengan topik penelitian. Hasil wawancara akan di dokumentasikan dengan catatan yang kemudian di sarikan oleh peneliti. 
Data sekunder berasal dari data tentang usaha yang di lakukan informan dan implementasi etika bisnis yang di pahami oleh informan tersebut. Dilakukan juga kajian pustaka dan literatur mengenai etika bisnis Islami yang di peroleh dari membeli buku etika bisnis Islam, membaca di ruang baca FEB Universitas Airlangga, browsing di internet dan lain - lain.

\section{Teknik Keabsahan Data}

Penelitian ini menggunakan teknik triangulasi dalam pemeriksaan keabsahan data. Terdapat tiga teknik triangulasi yakni triangulasi sumber, triangulasi teknik dan triangulasi waktu. Triangulasi yang digunakan dalam penelitian ini adalah triangulasi sumber yakni dengan cara membandingkan dan mengecek informasi yang di peroleh. Peneltian ini melakukan pengecekan ulang sumber dilakukan dengan jalan membandingkan hasil wawancara dengan isi suatu dokumen yang berkaitan.

\section{Teknik Analisis Data}

Setelah dilakukan pengumpulan
data dengan menggunakan
pendekatan di atas, kemudian
dilakukan teknik analisis data. Analisis
data dilakukan agar hasil yang di
peroleh dapat mudah dibaca dan
dipahami sebagai cara untuk
menyelesaikan

penelitian. Teknik analisis data yang digunakan dalam penelitian ini menggunakan teori milik Miles dan Huberman dalam Yin (2012) yang berjudul Studi Kasus Desain dan Metode yang terdiri dari tiga proses:

1. Data Reduction (Reduksi Data) Reduksi data adalah proses pemilihan, pemusatan perhatian pada penyederhanaan, pengabstrakan dantransformasu data kasar yang muncul dari catatan-catatan tertulis di lapangan.

2. Data Display (Penyajian Data)

Penyajian data dalam penelitian ini disajikan dalam bentuk teks naratif, bagan dan table yang di dapat dari hasil pengumpulan data pada Restoran "Mie Akhirat".

3. Conclusion Drawing/Verification (Menarik Kesimpulan/Verifikasi)

Pada tahap ini, peneliti mencari pola, tema, hubungan, persamaan, hal-hal yang sering timbul, hipotesis dan sebagainya hingga memperoleh suatu kesimpulan (Nasution, 1998: 130). Kesimpulan tersebut harus di verifikasi selama penelitian berlangsung dengan berbagai cara agar kredibilitasnya dapat dipertanggungjawabkan. Verifikasi penelitian ini menggunakan triangulasi data melalui observasi langsung, wawancara, dan 
dokumentasi terkait dengan aktivitas di Restoran "Mie Akhirat".

Teknik analisis khusus digunakan dipergunakan sebagai bagian dari strategi umum. Teknik analisis data yang digunakan dalam penelitian ini adalah penjodohan pola. Pola terseut berdasarkan teori empiris yang yang telah dikemukakan pada bab 2 dan berdasarkan proporsisi yang telah dibuat terkait implementasi etika binis islam pada Restoran "Mie Akhirat".

\section{HASIL DAN PEMBAHASAN}

Konsep implementasi etika bisnis Islam dari Haidar Naqvi (1993:86-105) terdiri dari kesatuan, kesetimbangan, kehendak bebas, tanggung jawab, kebenaran (kebajikan dan kejujuran). Berikut merupakan bentuk implementasi etika bisnis Islam dalam aktivitas bisnis Restoran Mie Akhirat.

1. Etika bisnis Islam dengan prinsip Kesatuan

Restoran Mie Akhirat menyajikan produk makanan dan minuman yang halal. Hal ini dapat dibuktikan karena produkproduk yang disajikan tidak mengandung unsur-unsur babi. Pihak Restoran Mie Akhirat sangat mengedepankan kualitas produknya, sehingga produknya dapat dinikmati semua kalangan. Setiap produk yang ditawarkan oleh pihak Restoran di media promosinya memang terbukti adanya ketika pelanggan memesan produknya.

Restoran Mie Akhirat selalu memperlakukan semua pelanggan dengan ramah, baik, dan sopan tidak ada yang dibeda-bedakan. Pihak Restoran Mie Akhirat memiliki misi untuk selalu mengutamakan kenyamanan para pelanggan, meskipun ada yang merasa diperlakukan kurang baik karena menganggap disambut dengan sambutan yang kurang baik. Penyajian dari Restoran bisa memakan waktu yang cukup lama apabila terdapat antrian yang cukup panjang.

Restoran yang terletak di sebelah Masjid Al-Falah ini sangat menghormati ketika adzan berkumandang maka musik di restoran dimatikan. Selain itu, setiap pelanggan dipersilahkan untuk sholat ditempat yang telah disediakan. Para staff Restoran Mie Akhirat juga diberikan kesempatan untuk menunaikan ibadah sholat terlebih dahulu. Pihak Restoran memberikan perlakuan yang sama kepada seluruh staff restoran dan memberikan tanggungjawab sesuai dengan tugasnya masing-masing.

2. Etika bisnis Islam dengan prinsip Kesetimbangan (Keadilan)

Restoran Mie Akhirat memiliki cara pemasaran yang menarik, yakni dengan mengunggah gambar produk makanan dan minumannya di sosial 
media yang mereka jadikan sebagai bahan promosi. Gambar yang diunggah di sosial media tersebut sama dengan apa yang disajikan oleh pihak Restoran Mie Akhirat kepada para pelanggannya. Pada sisi harga, harga yang ditawarkan oleh pihak Restoran Mie Akhirat disesuaikan dengan apa yang disajikan. Harga ditentukan dari harga pokok ditambahkan presentase keuntungan yang diambil sehingga dianggap pantas untuk dijual ke para pelanggan. Terdapat beberapa pelanggan yang merasa harga yang ditawarkan tidak sesuai atau terlalu mahal. Hal ini karena para pelanggan tersebut menganggap kualitas rasa yang disajikan tidak sebanding dengan harganya.

Manusia dalam berbisnis harus seimbang dalam mengejar duniawi dan akhiratnya. Restoran Mie Akhirat merupakan pendukung hal tersebut, hal itu ditunjukkan dengan menghentikan musik yang diputar dan memberikan kesempatan kepada karyawan dan pelanggan ditempat yang telah disediakan oleh pinak Restoran Mie Akhirat.

3. Etika bisnis Islam dengan prinsip Kehendak Bebas

Berdasarkan prinsip kehendak bebas dalam etika bisnis Islam Haidar Naqvi (1993:86-105), setiap pebisnis berhak membuat kesepakatan atau kontrak yang bertujuan untuk menguntungkan satu sama lain. Restoran Mie Akhirat memiliki komitmen untuk memenuhi setiap kontrak yang dibuatnya. Kontrak tersebut adalah kontrak antara pihak restoran dengan supplier, pelanggan maupun karyawan. Contoh komitmen kontrak pihak restoran dengan pelanggan adalah dengan memberikan pesanan yang sesuai dengan apa yang dipesan pelanggan. Selain itu, pihak pelanggan juga harus memenuhi prosedur yang telah ditetapkan oleh pihak restoran yakni dengan melakukan pemesanan dan pembayaran langsung di kasir pada jam operasional restoran.

Sebagai manusia, kita wajib untuk saling tolong-menolong. Kegiatan tolongmenolong tersebut bebas dilakukan oleh siapapun dan dengan cara apapun. Restoran Mie Akhirat menolong warga sekitarnya dengan memberikan lowongan pekerjaan kepada warga sekitarnya. Contohnya adalah dengan membuka lowongan sebagai pegawai dan pengelola parker sepeda motor dan mobil.

4. Etika bisnis Islam dengan prinsip Tanggung Jawab

Kebebasan tanpa batas adalah hal yang tidak mungkin. Setiap individu memiliki tanggung jawab yang yang 
harus di pertanggungjawabkan kelak.

Restoran Mie Akhirat bersikap professional dalam menjamu pelanggannya sebagai bentuk tanggungjawab restoran untuk memuaskan para pelanggannya. Bentuk tanggungjawab lainnya adalah pada gambar produk yang ditampilkan dalam media promosi sangat jelas dan sesuai dengan yang disajikan, ditambahi dengan informasi yang jelas sehingga pelanggan jelas dengan menu yang ditawarkan. Hal ini memudahkan para pelanggan dalam memesan. Pada saat memesanpun pihak restoran harus mengecek ketersediaan menu sebelum pelanggan melakukan pembayaran terhadap menu yang dipesan.

Restoran Mie Akhirat juga bisa diibaratkan dengan sebuah perusahaan yang pastinya memiliki limbah. Restoran Mie Akhirat yang berlokasi di dekat perumahan warga bertanggungjawab atas limbahnya. Hal ini ditunjukkan dengan membuang limbah setiap hari di tempat pembuangan sampah. Tujuannya adalah agar tidak menimbulkan bau yang dapat mengganggu warga sekitar.

5. Etika bisnis Islam dengan prinsip Kebenaran (Kebajikan dan Kejujuran)
Restoran Mie Akhirat selalu berusaha mengedepankan pelayanan. Hal ini ditunjukkan dengan selalu bersikap ramah, tidak membeda-bedakan pelanggan yang datang meskipun ada yang merasa disambut kurang baik oleh pihak restoran. Selalu menampilkan gambar menu dan menyampaikan informasi tentang menu yang disajikan dengan jelas dan sesuai dengan yang akan diberikan ke pelanggan. Proses pemesanan dan pembayaran pun dibuat untuk memudahkan para pelanggan yakni dengan langsung memesan dan membayar di kasir jadi pelanggan dapat mengetahui ketersediaan produk juga.

Berbuat kebajikan adalah sebuah keharusan yang dilakukan oleh setiap orang. Restoran Mie Akhirat juga melakukan kebajikan dengan selalu menyisihkan pendapatan, yang nantinya akan diberikan kepada orang yang lebih membutuhkan. Restoran Mie Akhirat juga memberikan kesempatan kepada para pelanggan untuk ikut dalam kegiatan amal. Hal ini ditunjukkan dengan pembuatan satu menu khusus, dimana setiap hasil penjualan menu tersebut akan disumbangkan ke yayasan ataupun lembaga lain yang membutuhkan.

\section{SIMPULAN}


Berdasarkan pembahasan yang telah dijelaskan, maka didapatkan kesimpulan sebagai berikut:

1. Prinsip-prinsip etika bisnis Islam menurut Haidar Naqvi (1993:86-105) diwujudkan dalam aktivitas bisnisnya sebagai berikut:

a. Prinsip Kesatuan

Produk yang ditawarkan halal, melayani pelanggan dengan baik tidak memperlakukannya berbeda, selalu menyisihkan pendapatan untuk membantu masyarakat lain yang membutuhkan.

b. Prinsip Kesetimbangan

Penentuan harga oleh pihak Restoran Mie Akhirat dari harga pokok penjualan sehingga pas dengan produk yang disajikan. Tetapi ada beberapa pelanggan yang merasa produk yang disajikan dengan harganya tidak sesuai, mereka menganggap harga yang ditawarkan terlalu mahal.

c. Prinsip Kehendak Bebas

Penjelasan tentang produk dijelaskan dengan benar dan pada saat pemesanan selalu di cek ketersediaannya. Selalu menjaga komitmen kepada pihak-pihak yang berhubungan dengan keberlangsungan Restoran Mie Akhirat. Semua pelanggan melakukan pemesanan dan pembayaran sesuai dengan peraturan yang telah ditetapkan oleh pihak Restoran Mie Akhirat.

d. Prinsip Tanggungjawab

Promosi melalui media sosial menggunakan gambar produk yang jelas dan sesuai dengan apa yang disajikan oleh Restoran Mie Akhirat. Restoran Mie Akhirat selalu berusaha bersikap professional untuk memberikan pelayanan terbaik bagi para pelanggannya.

e. Prinsip Kebenaran (Kebajikan dan Kejujuran)

Bersikap ramah, baik, dan jujur kepada semua pelanggan tanpa membedabedakan pelanggan. Selalu menyisihkan pendapatan untuk membantu masyarakat yang membutuhkan, dan selalu menerima tanggapan yang diberikan dari para pelanggan dengan baik.

\subsection{Saran}

Saran yang dapat diberikan berdasarkan hasil dari penelitian adalah:

1. Untuk pihak Restoran Mie Akhirat

a. Harga yang ditawarkan dengan produk yang disajikan diharap dapat dihitung ulang dalam penentuan harganya karena beberapa pelanggan yang mengeluhkannya. Apabila tidak, bisa dengan memberikan kualitas masakan yang lebih sehingga harga yang ditawarkan dianggap sesuai. 
Saran lain adalah dengan memberikan informasi atau mengkomunikasikan menu dengan jelas sehingga pelanggan akan merasa bahwa harga yang ditawarkan sesuai.

b. Bagi pelayanannya diharap dapat selalu menerapkan 3S yakni Senyum, Salam, dan Sapa. Karena terdapat beberapa pelanggan yang beranggapan bahwa pelayan memberikan sambutan yang kurang menyenangkan, mungkin karena kurang senyum atau kurang ramah. Hal ini bisa dikarenakan karyawan yang lelah, jadi sebaiknya dibuatkan sistem rotasi pelayan agar pelayan di Restoran dapat beristirahat dan selalu tampil segar ketika menyambut pelanggan.

c. Menggunakan media sosial yang dimiliki untuk berkomunikasi dengan para pelanggan. Hal ini karena terdapat beberapa pelanggan yang hanya menggunakan media sosial milik Restoran Mie Akhirat untuk upload gambar atau hal lain yang tidak memberikan tanggapan kritis kepada pihak Restoran Mie Akhirat.

d. Mengunggah semua kegiatankegiatan sosial yang dilakukan pihak Restoran Mie Akhirat supaya para pelanggan tahu kegiatan sosial apasaja yang dilakukan oleh pihak restoran sehingga mereka merasa tergugah dan ingin ikut berpartisipasi.
2. Untuk peneliti selanjutnya

Penelitian ini masih banyak memiliki kekurangan dan keterbatasan, sehingga bagi peneliti selanjutnya diharapkan dapat meneliti dengan topic yang sama dengan detail penelitian yang lebih mendalam mengenai prinsip etika bisnis Islam Haidar Naqvi (1993:86-105). Saran untuk peneliti selanjutnya adalah dengan dengan meneliti bentuk implementasi etika bisnis Islam pada jenis bisnis yang lain, dengan menggunakan alat ukur atau criteria yang lebih terfokus sehingga dapat memberikan gambaran yang jelas mengenai bagaimana praktik bisnis dalam Islam yang harus dilakukan oleh masyarakat muslim bahkan nonmuslim.

\section{DAFTAR PUSTAKA}

Afifudin, Beni dan Ahmad Saebani. 2009. Metodologi Penelitian Kualitatif. Pustaka Setia

Afzalurrahman. 2000. Muhammad Sebagai Seorang Pedagang (Muhammad as a Trader). Yayasan Swarba Bhummy

Arifin, Johan. 2009. Etika Bisnis Islami. Semarang: Walisongo Press.

Azizaturrohman, Siti Nur.2014. Pemahaman Etika Berdagang Pada Pedagang Pasar Wonokromo Surabaya (Studi Kasus 
Pedagang Buah). Skripsi tidak diterbitkan. Universitas Airlangga.

Beekun, Rafiq Issa. 1997. Islamic Business Ethict, Virginia: International Institute of Islamic Thought

Brehm, S.s \& Kassin, S.M. 1990. Social Psychologi. Boston: Houghton Mifflin

Chaplin, J. P. 1999. Kamus Lengkap Psikologi. Jakarta : Rineka Cipta.

Departemen Agama RI. 2009. Syamil AlQur'an (Al-Qur'an Terjemahan Perkata). Bandung: CV Haikal Centre

Fakhri, Madjid. 1996. Etika dalam Islam. Zakiyuddin B. Yogyakarta: Pustaka Belajar dan Pusat Studi Islam-UMS

Gitosudarmo, Indriyo. 1999. Pengantar Bisnis. Yogyakarta: BPFE

Hardjanto, Amirullah I. 2005. Pengantar Bisnis. Bandung: Graha Ilmu

Hizrian, Jundi. 2014. Konsep Bisnis Dalam Islam. Tidak Diterbitkan. Universitas Muhammadiyah Tangerang.

John, Mc. Leish. 1986. Behaviorisme sebagai Psikologi Perilaku Modern. Terjemahan A. Latief Zachru. Bandung: Tarsito

Mariampolski. 2001. Metode Penelitian Kualitatif. Jakarta: Prenhallindo Maryani dan Ludigdo. (2001). Survey atas Faktor-faktor yang Mempengaruhi Sikap dan Perilaku Etis Akuntan. Jurnal TEMA2 (1):49-62.

Moleong, Lexy J. 2002. Metode Penelitian Kualitatif. Bandung: PT. Remaja Rosdakarya
Muhammad dan Lukman Fauroni. 2002. Visi Alquran Tentang Etika dan Bisnis. Jakarta: Salemba Diniyah.

Muhammad. 2004. Etika Bisnis Islami. Unit Penerbit dan Percetakan Akademi Manajemen Perusahaan YKPN: Yogyakarta

Munawwir, Ahmad Warson. 1984. Kamus AlMunawwir. Yogyakarta: PP Krapyak.

Muslich, M.M. 2004. Etika Bisnis Islami: Landasan Filosofis, Normatif, dan Substansi Implementatif. Jakarta: Ekonisia

Nasution. 1998. Metodologi Penelitian Naturalistic, Bandung : PN. TARSITO

Nawatmi, Sri. 2010. Etika Bisnis dalam Persektif Islam. Fokus Ekonomi (FE) Vol.9, No.1.

Naqvi, Syed NAwab. 1993. Ethict and Economics: An Islamic Syntesis, diterjemahkan oleh Husin Anis: Etika dan IImu Ekonomi Suatu Sintesis Islami. Bandung: Mizan

Shihab, Quraish. 2013. Wawasan Al-Quran: Tafsir Tematik Atas Berbagai Persoalan Umat. Jakarta: Mizan.

Sugiyono. 2011. Metodologi Penelitian Kuantitatif Kualitatif dan R\&D. Bandung: ALFABETA

UU No. 8 Tahun 1999 tentang Perlindungan Konsumen

Yin, Robert. 2012. Studi Kasus Desain dan Metode. Jakarta: Rajawali Press. 